Expanding by the binomial theorem:

$$
\frac{1}{A}=\frac{B}{10^{K}}\left[1+\frac{2}{10^{K}}+\frac{2^{2}}{10^{2 K}}+\frac{2^{3}}{10^{3 K}}+\ldots .\right]
$$

When calculating $\frac{1}{A}$ in decimals, $B$ must first be expressed as a decimal and it depends on the number of figures in $B$ whether the progressive doubling is immediately apparent or not. In the case of $1 / 25 \cdot 4$, if we let $K$ equal 6 then $10^{K}-2$ equals 999,998 and $B=39370$. Thus :

$$
\begin{aligned}
\frac{1}{25 \cdot 4} & =\frac{39370}{10^{6}}\left[1+\frac{2}{10^{6}}+\frac{4}{10^{12}}+\frac{8}{10^{18}}+\ldots . .\right] \\
& =0.03937+0.00000007874+\ldots .
\end{aligned}
$$

W. M. ANDERSON

B. E. ROBINSON

Mullard Radio Valve Co.,

New Road, Mitcham Junction, Surrey.

${ }^{1}$ Anderton, Mrs. P., and Bigg, P. H., Nature, 200, 730 (1963).

\section{Dissemination and Storage of Scientific Information in the United Kingdom}

The storage and retrieval of scientific information is a subject the study of which has received scant official support in Great Britain; indeed until recently the small volume of research in this field was mostly financed from abroad. Likewise, as stated in the leading article in Nature of May 23, Government support for non-conventional means of dissemination and storage of scientific information is very disappointing. The fact that this information is the basic raw material of a research 'industry' with an annual turn-over of several hundred million pounds allows one to sense the seriousness of this lack.

It may be of interest to put on record what has already been done-thanks to the generous help of a number of industrial organizations and a local authority-to build up the nucleus of an organization to provide the inform. ation needs of modern research. In late 1962, a number of persons, bringing together experience of academic and industrial research and industrial and governmental administration, formed themselves into a Council and thereby founded the Scientific Documentation Centre, Ltd. This organization was charged inter alia with the purposes of compiling central collections of scientific data, of supplying scientific information services and of carrying out research aimed at improving the means of handling scientific information and data.

Substantial progress has already been made with these tasks. Research has shown that papers germane to each of a wide range of subjects are widely scattered throughout the literature-important papers often appearing in the most unexpected journals. As a result of this intelligence, the Centre has built up a series of 'Current Awareness Services' which bring to the individual scientist and to libraries up-to-date notification of papers on subjects of interest to them. This covers more than 1,100 journals, and includes the U.S. Government research reports and a large number of Russian journals. 'Current Awareness Services' are already operating on such subjects as: astronomy; arsenic; carbohydrate chemistry; carbon; carcinogens and carcinostats; cell membranes; ceramics and glass; chromatography; chemical processing; computer applications; cryogenics and superconductors; digitization; electroencephalography; fluorimetry; gas chromatography; geophysics; infra-red of natural phenomena; integrated circuits; interferometers; lasers; management and personnel; marine biology; mass spectroscopy; molluscicides; non-conventional aromatic systems; nuclear magnetic resonance; optical rotary dispersion; packaging; paper technology; pattern recognition; plastics-materials and techniques; polarography and related techniques; polymer analysis; spectrometers (manufacture); spectroscopy (applications); tobacco; terpenes, perfumes and flavours; triazines; town gas; ultra-high pressure; ultra-high vacuum; ultrasonics; water desalination. The Centre has been able to provide material for all 'Current Awareness' requests so far received.

Progress has also been made in the compilation of central collections of scientific data. The Centre's Spectra Index, which we regard as a pilot experiment for larger indexes, now contains some 20,000 spectra, the majority not being available in searchable form elsewhere. The Spectra Index now comprises the largest generally available collection of spectra or spectral data originating in Europe.

Though the Centre has made substantial progress since its foundation, despite the lack of official financial support, given greater resources, the nucleus that has been set up could very rapidly expand to give more complete and more numerous services to British research.

\section{P. S. Davison}

Scientific Documentation Centre, Ltd.,

Halbeath House,

Dunfermline,

Scotland.

\section{Early Recognition of Galileo's Work in England}

THIs year, the four hundredth anniversary of the birth of Galileo, has been the occasion of widespread consideration of all aspects of the work of the master, among which the contemporary reception of his work in England is of particular interest to us*. Poets and philosophers, men of general learning and men of science have been cited ${ }^{1}$, but among them I have never seen Robert Burton.

Burton's Anatomy of Melancholy, which contains many references to Galileo, is a sage and extremely individual consideration of the problems of life, characterized by pertinent quotations from, perhaps, every author accessible at the time. As an example, we may take "every schoolboy hath the famous testament of Grunnius Corocotta Porcellus at his finger ends". Keats, Sterne and Samuel Johnson, men of very different temperament, were, among other celebrities, devoted to the Anatomy, the first edition of which was published in 1621 .

In his book, Burton, who died just two years before Galileo, refers to Gajileo's observation of the Medicean stars and of the ill-resolved ring of Saturn-". . . and that those severall Planets, have their severall Moones about them, as the Earth hath hers, as Galileo hath already evinced by his glasses, foure about Juppiter, two about Saturne (though Sittius the Florentine cavill at it)": to his observations on the Moon-". . . hils and dales, and such like concavities, if we may subscribe to, and beleeve Galilies observations": and in the second edition, 1624 , to the discovery of the nature of the Milky Way"... and that via lactea, a confused light of small starres". In later editions he also refers to Galileo's obs9rvations of the sun-spots and consideration of the tides. There are also many passing allusions to his work.

The great scholar clearly had an understanding of the significance of Galileo's work and must have been responsible for bringing it to the notice of a great part of the world of learning in Britain.

The Athenæum,

$$
\text { E. N. Da C. ANDrade }
$$

Pall Mall,

London, S.W.1.

- See also Nature, 201, 653 (1964).-Editor.

${ }^{2}$ See in particular the excellent detailed discussion by Marie Boas Hall, to be published in the Notre Dame Galileo volume. 